\title{
Extracting economic value from breweries wastewater: a review
}

\begin{abstract}
Worldwide breweries are known to use large volumes of water. Between 10 and $20 \mathrm{~m}^{3}$ of water yields $1 \mathrm{~m}^{3}$ of beer. This translates to over $90 \%$ of wastewater. The world produced $1.94 \times 10^{8} \mathrm{~m}^{3}$ of beer in 2018 . Of the total production $1.48 \times 10^{7} \mathrm{~m}^{3}$ of beer were produced from Africa with Uganda contributing up to $4.1 \times 10^{5} \mathrm{~m}^{3}$. Uganda's major producing industries being Uganda Breweries Limited and Nile Breweries Limited. Uganda's brewery sector generates between $3.69 \times 10^{6}$ to $7.79 \times 10^{6} \mathrm{~m}^{3}$ of wastewater annually that could otherwise be of importance. This wastewater is characterized by high organic matter content with COD, BOD and TSS ranging between 2,000 to $10,000 \mathrm{mg} \mathrm{L}^{-1}, 1,200$ to $7,000 \mathrm{mg} \mathrm{L}^{-1}$ and 2,901 to $3,000 \mathrm{mg} \mathrm{L}^{-1}$ respectively. Whereas little information has been published regarding the current use of wastewater in Uganda by the Key players, elsewhere in the world the wastewater has been treated for re-use using Anaerobic Sequencing Batch Reactor and membrane bioreactors, for electricity generation using microbial fuel cell and for biogas production using Veolia Bio Bed Technology. The generated sludge has successfully been used as an Organic Fertilizer and a raw material for Organic Fertilizers production in different parts of the world. The process by-products such as spent grain, spent hops and surplus yeast have been used majorly in fertilizers and animal feeds. The purpose of this review article was to explore potential uses of the wastewater in that could apply for Uganda.
\end{abstract}

Keywords: brewery, economic value, organic matter, total soluble solids wastewater
Volume 6 Issue I - 202 I

\author{
Paddy Ainebyona, Noble Banadda, Nicholas \\ Kiggundu \\ Department of Agricultural and Biosystems Engineering
} Makerere University, Uganda

\author{
Correspondence: Paddy Ainebyona, Agricultural and \\ Biosystems Engineering, Makerere University, P.O Box 7062 \\ Kampala, Central region, Uganda, Tel +256778066765 , \\ Email painebyon@caes.mak.ac.ug
}

Received: December 28, 2020 | Published: February 02, 2021

\section{Background}

Brewery industries use large volumes of water to execute several beer production processes such as malting, mashing, wort filtration, wort boiling, fermentation, maturation, stabilization and clarification..$^{1-3}$ Generally, to produce $1 \mathrm{~m}^{3}$ of beer, a volume of wastewater between $10-20 \mathrm{~m}^{3}$ is produced. ${ }^{4}$ The properties of this wastewater referred to as brewery wastewater (BW) herein is influenced by the brewing process and it has characteristics similar to those of the semi-solid byproducts. The semi-solid byproducts include spent grains, residual brewing yeast and trub. ${ }^{5}$ These are responsible for the high organic matter content of the BW. ${ }^{1}$ The effluents have high contents of BOD and COD of up to $1,000 \mathrm{mg} \mathrm{L}^{-1}$ (EspinozaQuiñones et al., ${ }^{6}$ ) and $1,420 \mathrm{mgL}^{-1}$ (Papadopoulos et al., ${ }^{4}$ ) respectively. TSS range between 2,901 to $3,000 \mathrm{mgL}^{-1} .^{7}$ Due to these properties, the treatment of this wastewater is necessary before disposal. ${ }^{1}$ Most breweries treat wastewaters using aerobic activated sludge systems assisted by chemical coagulation. ${ }^{8}$ These systems are quite costly and energy demanding and are therefore unsustainable in the long run. ${ }^{1}$ was has resulted in some breweries disposing BW to emove water such as rivers and also to municipal sewer systems thus resulting into conflicts among the downstream recipients. ${ }^{9}$

Several studies and technologies have to find feasible and sustainable alternatives for reusing BW.,5 The overall target in utilizing these approaches is to find the sustainable ways of getting value from wastewater. Some studies have focused on BW treatment for recycling ${ }^{3}$ using Anaerobic Sequencing Batch Reactor (ASBR). The process reduced on costs of water during production. BW was successfully treated using fluidized bed bioreactors ${ }^{10}$ granular sludge reactors, Up-flow Activated Sludge Blanket (UASB) and Expanded Granular Sludge Bed (EGSB). ${ }^{11} \mathrm{BW}$ was used as a substrate to generate bioelectricity in China using Microbial Fuel Cell (MFC). ${ }^{12}$ The MFC indicated an emf of $0.578 \mathrm{~V}$ at inpower density of $9.52 \mathrm{~W} / \mathrm{m}^{3}(264 \mathrm{~mW} /$ $\mathrm{m}^{2}$ ) illustrating a potential adaptation of the wastewater in generating electricity through the conversion of chemical energy available in
Organic matter into electrical energy. ${ }^{13}$ Also, the wastewater has been treated to generate biogas due to its high Organic matter composition. ${ }^{14}$ The process proceeded through anaerobic digestion using Veolia Bio Bed Technology in which up to $85 \%$ COD was extracted. Manjunatha \& Bhaskar, ${ }^{15}$ used BW to irrigate maize and analyzed its effect on soil quality. The study showed a significant increase grain and Stover yield for maize and an overall improvement on soil quality compared to fresh water. BW has been aerobically treated to obtain sludge for use as an organic fertilizer in Sri Lanka. ${ }^{16}$ The sludge was sun dried tested to contain valuable nutrients that improved yield of pumpkin and chili in the Country through improving water retention. This review targets addressing feasible ways that could potentially be applicable to the case of Uganda and other developing countries with large volumes of wastewater generated.

BW consists of high metals such as cadmium, lead, and copper ${ }^{17}$ which pollute the ecosystem. The wastewater requires treatment before release to the environment for the safety of living organisms in the ecosystem. ${ }^{18}$ Wastewater from agriculturally based processing industries is easily decomposable due to high organic matter composition. ${ }^{19}$

\section{Process of beer production and how BW is generated}

Beer production involves blending and fermentation of malted barley (or other cereals), with sugar (or corn syrups) and hops catalyzed by yeast. ${ }^{20}$ The detailed beer production process is described in Figure 1. The process starts with milling malted grains to increase surface area to volume ratio to promote effective and efficient extraction of required substances. ${ }^{8}$ Milling is followed by mixing the malted flour with gelatinized adjunct and water to form a mash. The process is catalyzed by infusion and decoction heating. Heating takes place in a mash tun during which starch is hydrolyzed to form sweet wort liquor. The process is followed by the addition of hot water at $71-82^{\circ} \mathrm{C} .{ }^{8}$ During decoction, the mixture separated from the mash is heated to boiling after which the mixture is returned to the mash tun. ${ }^{8}$ 


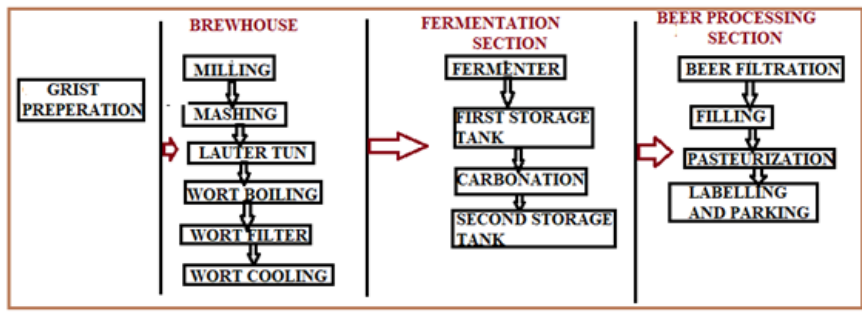

Figure I Beer production stages (Brewing). ${ }^{8,22}$

This is followed by wort separation which takes place in the lauter tun after which the mash is moved to a lautering vessel for settlement. In the lautering vessel, water is sprayed to decant any residual extract that formed around the grain bed. Wort boiling and evaporation processes last for about 1-1.5h during which wort is sterilized and grain pepsin is coagulated. Hops are added to remove vital oils and bitter resins that are later strained off. The boiled wort is clarified by sedimentation and is cooled using air or liquid media. ${ }^{8}$ This is followed by oxygenation and blending with yeast in the fermenters. Yeast digests fermentable sugars anaerobically to alcohol and carbon dioxide gas as illustrated by Equation 1 .

ADP and ATP represent Adenosine Diphosphate and Adenosine Triphosphate respectively.

The sugars exploited during fermentation include glucose, fructose, sucrose, maltose, and maltotriose respectively. ${ }^{8}$ The fermentation process takes about 7 days or more depending on the brewer's size. ${ }^{21}$ The carbon dioxide gas produced dissolves in beer which reduces final carbonation. ${ }^{8}$ Beer production is concluded by conditioning through cooling and storage to give room for maturation and stabilization. During conditioning, a recommendable amount of water up to $50 \%$ is added. ${ }^{8}$ Pasteurization is carried out to destroy biological contaminants thus increasing beer's shelf life.

\section{Estimation of wastewater production in Ugandan breweries}

Several studies targeting beer consumption have indicated an increasing demand over others. ${ }^{5}$ Beer lies in fifth place among the world's most consumed beverages behind tea, carbonated drinks, milk, and coffee with an average consumption rate of $0.023 \mathrm{~m}^{3}$ person $^{-1} \mathrm{yr}^{-1} .^{23}$ The best ten beer-producing countries generated about $1.19 \times 10^{7} \mathrm{~m}^{3}$ in $2014^{24}$ and about $4.1 \times 10^{5} \mathrm{~m}^{3}$ produced from Uganda annually ${ }^{25}$ produced from Nile Breweries and Distillers Limited as well Uganda breweries limited and some other small scale brewers. The production trend is shown in Figure 2.

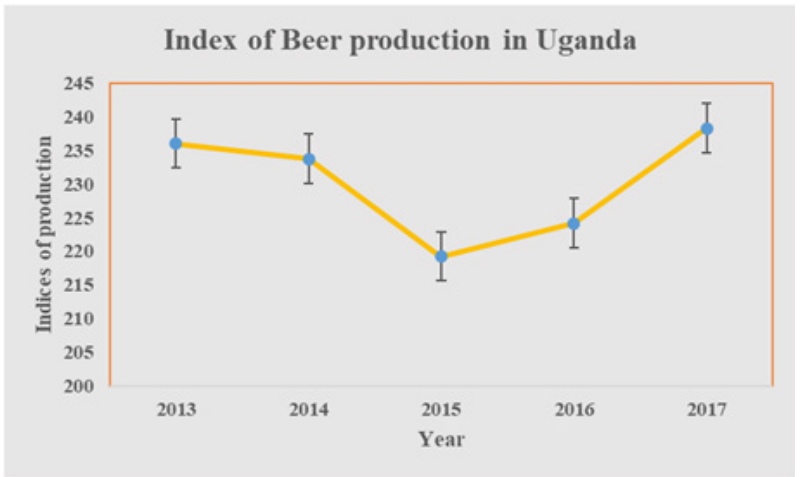

Figure 2 Beer production in Uganda for the period 2013-2017.25
Water is a very important reagent in brewing beers. ${ }^{1,26}$ The quantity of water used to make $1 \mathrm{~m}^{3}$ of beer ranges between $10-20 \mathrm{~m}^{3} .^{8,27,28}$ This water is required at all stages of brewing as indicated in Table 1. Water is also used in heating and cooling of heat exchangers as well as cleaning packaging vessels and production machines. ${ }^{8}$ This is an indication of how much of this water eventually becomes wastewater.

Table I Water consumption in the Brewery process. ${ }^{8,28}$

\begin{tabular}{ll}
\hline Area & $\begin{array}{l}\text { Specific water consumption }\left(\mathrm{m}^{3} / \mathrm{hL}\right. \\
\text { beer produced })\end{array}$ \\
\hline Brewhouse & $0.17-0.26$ \\
Cold storage & $0.1 \mathrm{I}-0.24$ \\
Fermentation cellar & $0.04-0.08$ \\
Storage cellar & $0.0 \mathrm{I}-0.06$ \\
Filtering cellar & $0.01-0.08$ \\
Bottling cellar & $0.09-0.10$ \\
Cask cellar & $0.01-0.12$ \\
Miscellaneous & $0.03-0.40$ \\
Total Process & $0.47-1.33$ \\
\hline
\end{tabular}

According to Manjunatha and Bhaskar, ${ }^{15}$ the brewing process produces between 3 to $10 \mathrm{~m}^{3}$ of wastewater effluent for every $1 \mathrm{~m}^{3}$ of beer as much of the excess water is heated in brewing and cleaning. According to Olajire, ${ }^{8}$ the wastewater is an excess of what is left after waste wort liquor and spent grain from brew house, trub from the whirlpool, spent yeast from fermenters, centrifuge overflow, pasteurization, external keg washing, filtration process, carbon filters, bottle filler, can filler, residual beer rejected beer during improper filling and packaging as well as returned beer that has either expired or has been deemed unacceptable.

In Uganda, $4.1 \times 10^{5} \mathrm{~m}^{3}$ of beer produced generates about $3.69 \times 10^{6}$ to $7.79 \times 10^{6} \mathrm{~m}^{3}$ of wastewater annually from formal breweries of Uganda Breweries Limited and Nile Breweries Limited. The waste generated from informal brewers is unknown.

\section{BW physical and chemical composition}

To understand the use of $\mathrm{BW}$, it is important to determine physical and chemical properties that are known to influence the treatment potential. BW is highly biodegradable although composed of highly complex organic mixtures. ${ }^{29,30}$ It is characterized by high BOD, COD and TSS. COD value in wastewaters indicates the level of decomposable and non-decomposable organic matters. ${ }^{31} \mathrm{BOD}$ reflects the nutrient value of wastewater whereas TSS value shows suspended solids in wastewater. BW has higher levels of sugar and alcohol compared to domestic wastewater ${ }^{20}$ and is largely nontoxic. ${ }^{15}$ There are also recorded variations in flow and composition of BW due to different effluent sources. ${ }^{3}$ The chemical composition of BW is summarized in Table 2.

Table 2 Composition of brewery wastewater Source:1,22,30

\begin{tabular}{ll}
\hline Characteristic & Range \\
\hline BOD $\left(\mathrm{mg} \mathrm{L}^{-1}\right)$ & $\mathrm{I}, 200-3,600$ \\
COD $\left(\mathrm{mg} \mathrm{L}^{-1}\right)$ & $2,000-6,000$ \\
COD:BOD ratio & 1.667 \\
VFA $\left(\mathrm{mg} \mathrm{L}^{-1}\right)$ & $\mathrm{I}, 000-2,500$
\end{tabular}


Table continued...

\begin{tabular}{ll}
\hline Characteristic & Range \\
\hline TSS $\left(\mathrm{mg} \mathrm{L}^{-1}\right)$ & $2,90 \mathrm{I}-3,000$ \\
TDS $\left(\mathrm{mg} \mathrm{L}^{-1}\right)$ & $2,020-5,940$ \\
Ethanol $\left(\mathrm{mg} \mathrm{L}^{-1}\right)$ & $400-1,690$ \\
Ph & $3-12$ \\
Total Kjeldhal Nitrogen, $\left(\mathrm{mg} \mathrm{L}^{-1}\right)$ & $25-80$ \\
TS $\left(\mathrm{mg} \mathrm{L}^{-1}\right)$ & $5,100-8,750$ \\
Orthophosphate & $10-50$ \\
,(mg L-1) & \\
Temperature $\left({ }^{\circ} \mathrm{C}\right)$ & $18-40$ \\
\hline
\end{tabular}

\section{Treatment of brewery wastewater}

\section{Conventional methods}

BW has a high COD value from its organic matter resulting from sugars, starch, volatile fatty acids, ethanol, produced during brewing. ${ }^{32}$ Due to large variations in chemical composition (Table 2), breweries require wastewater pretreatment before reuse or disposal. This is carried out to reduce organic load before disposal to the municipal sewer systems. Pretreatment is carried out to alter physical as well as chemical and biological properties. ${ }^{33}$ Unit operations and processes involved in BW treatment are described in Table 3.

Table 3 Wastewater unit operation and processes'

\begin{tabular}{|c|c|}
\hline Unit operation & Processes involved \\
\hline \multirow{6}{*}{ Physical } & Screening \\
\hline & Comminution \\
\hline & Flow equalization \\
\hline & Sedimentation \\
\hline & Flotation \\
\hline & Granular medium filtration \\
\hline \multirow{4}{*}{ Chemical } & Chemical precipitation \\
\hline & Adsorption \\
\hline & Disinfection \\
\hline & Chlorination \\
\hline \multirow{6}{*}{ Biological } & Activated sludge processes \\
\hline & Aerated lagoons \\
\hline & Trickling filters \\
\hline & Pond stabilization \\
\hline & Anaerobic digestion \\
\hline & Biological nutrient removal \\
\hline
\end{tabular}

\section{Physical processes}

Physical processes aim at reducing rough solid particles and are unable to remove dissolved pollutants. ${ }^{1}$ During physical treatment, sedimentation of BW is carried out to allow suspended pollutants to settle at the top. Sedimentation alone is not efficient even after the coagulation of wastewater ${ }^{1}$ and thus other processes are advised to treat BW to the required standards indicated in Table 4.
Table 4 Quality standards for rinsing and cooling water ${ }^{1,35}$

\begin{tabular}{|c|c|c|c|}
\hline & $\begin{array}{l}\text { Quality } \\
\text { Standards } \\
\text { for rinsing } \\
\text { water }\end{array}$ & $\begin{array}{l}\text { Quality } \\
\text { standards for } \\
\text { cooling water }\end{array}$ & $\begin{array}{l}\text { Quality } \\
\text { standards } \\
\text { for drinking } \\
\text { water }\end{array}$ \\
\hline $\operatorname{COD}\left(\mathrm{mgO}_{2} \mathrm{~L}^{-1}\right)$ & $0-2$ & $0-2$ & $0-2$ \\
\hline $\mathrm{Na}^{+}\left(\mathrm{mg} \mathrm{L}^{-1}\right)$ & $0-200$ & I & 20 \\
\hline $\mathrm{Cl}^{-}\left(\mathrm{mg} \mathrm{L}^{-1}\right)$ & $50-250$ & 1 & 25 \\
\hline $\mathrm{pH}$ & $6.5-9.5$ & $6.5-9.5$ & $6.5-9.5$ \\
\hline $\begin{array}{l}\text { Conductivity ( } \mu \mathrm{s} \\
\mathrm{cm}^{-1} \text { ) }\end{array}$ & 1 & 1 & 400 \\
\hline
\end{tabular}

Sedimentation is followed by membrane filtration to further improve the quality of water during treatment. Membrane filters are grouped using pore sizes into four classes; microfiltration, ultrafiltration, nano-filtration and hyperfiltration in the descending order of pore sizes and the properties are indicated in Table $5 .{ }^{34}$

Table 5 Characteristics of membrane processes ${ }^{34}$

\begin{tabular}{|c|c|c|c|c|}
\hline Process & $\begin{array}{l}\text { Operating } \\
\text { pressure } \\
\text { (bars) }\end{array}$ & $\begin{array}{l}\text { Pore size } \\
(\mathrm{mm})\end{array}$ & $\begin{array}{l}\text { Molecular } \\
\text { weight } \\
\text { (Cut off } \\
\text { range) }\end{array}$ & $\begin{array}{l}\text { Size cut } \\
\text { off range } \\
(\mathrm{nm})\end{array}$ \\
\hline Microfiltration & $<4$ & $100-3,000$ & $>500,000$ & $50-3,000$ \\
\hline Ultrafiltration & $2-10$ & $10-200$ & $\begin{array}{l}1,000- \\
1,000,000\end{array}$ & $15-200$ \\
\hline $\begin{array}{l}\text { Nano } \\
\text { filtration }\end{array}$ & $5-40$ & $1-10$ & $100-20,000$ & $1-100$ \\
\hline $\begin{array}{l}\text { Reverse } \\
\text { osmosis }\end{array}$ & $15-150$ & $<2$ & $<200$ & $<1$ \\
\hline $\begin{array}{l}\text { (Hyper } \\
\text { filtration) }\end{array}$ & & & & \\
\hline
\end{tabular}

Membrane filters operated using two ways the dead-end and cross flow as described in Figure 3.,34 In the dead-end type, feedwater passes through the membrane while the large impurities are retained at the filler module for recirculation. ${ }^{1}$ Braeken et al., ${ }^{35}$ applied nano filtration to recycle $\mathrm{BW}$ that saw a $\mathrm{COD}, \mathrm{Na}^{+}$, and $\mathrm{Cl}$ removal of $100 \%, 55 \%$ and $70 \%$ respectively. Reverse osmosis (RO) is employed to remove organic salts from wastewater based on the rejection of sodium chloride from 95-99.5\%. Madaeni and Mansourpanah ${ }^{36}$ used reverse osmosis to extract COD from BW up to $90 \%$.

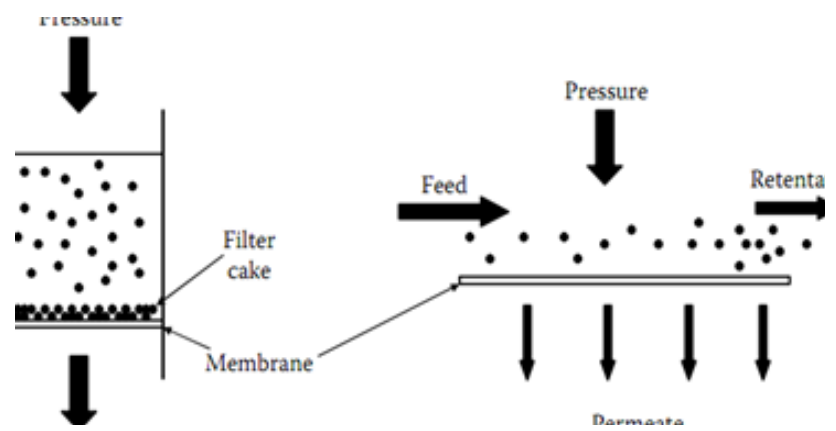

Figure 3 Two forms of membrane filtration (A) Dead end and (B) Cross Flow.

\section{Chemical processes}

Chemicals are used to regulate chemical composition in wastewater ${ }^{33}$ that eventually alter $\mathrm{pH}$ of the water. Coagulation and flocculation precipitate colloidal matter from wastewater ${ }^{1}$ causing smaller aggregates leading to destabilization whereas flocculation 
causes larger aggregates through shearing colloidal matter. Nonthermal Quenched plasma has been used during chemical wastewater treatment. Doubla et al., ${ }^{37}$ used humid air plasma from electric gliding arc discharge to reduce organic pollutants in BW showing a BOD removal at a concentration of 385 and $1,018 \mathrm{mg} \mathrm{L}^{-1}$ of 74 and $98 \%$ respectively.

\section{Biological processes}

Biological processes explore the use of microorganisms by aerobic and anaerobic processes. Biological processes have three main advantages; the treatment process is efficient in COD and BOD recovery, the recovery efficiency ranges between $80-90 \%$, the process becomes mature at low investment costs. ${ }^{1}$ Membrane bioreactors (MBR) use biological treatment using activated sludge and membrane filtration described in Figure 4. ${ }^{1}$
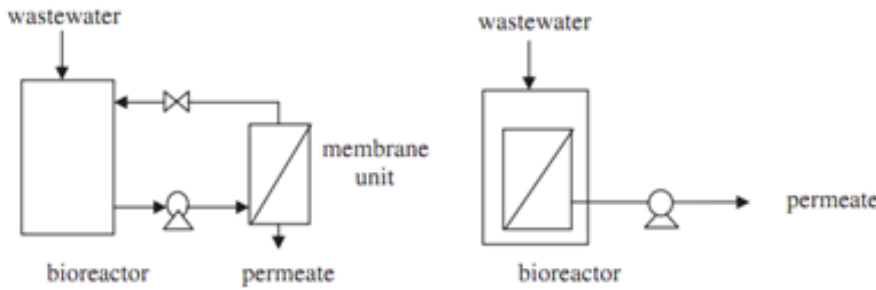

Figure 4 Membrane bioreactor configurations (A) Side-stream and (B) Submerged.

In side-stream MBR, membrane units lie outside the reactor and wastewater circulates over the loop. In the submerged MBR, the membrane units lie inside the reactor thus wastewater becomes submerged in the membrane units. According to $\mathrm{Li}$ and $\mathrm{Chu},{ }^{38}$ up to $60 \%$ of TOC were removed by membrane bioreactors. Table 6 illustrates the operating parameters for some anaerobic digestionultrafiltration processes.

Table 6 Mean operating criteria of anaerobic digestion-ultrafiltration plants for treating brewery wastewaters

\begin{tabular}{ll}
\hline Operating parameter/results & Brewery \\
\hline Volume of digester & 0.05 \\
Operational period (months) & 3 \\
Feed COD $(\mathrm{kg} / \mathrm{L})$ & 6.7 \\
Permeate COD $(\mathrm{kg} / \mathrm{L})$ & 0.18 \\
COD removal $(\%)$ & 97 \\
Space load rates $\left(\mathrm{kg}\right.$ COD $\left./ \mathrm{m}^{3} . \mathrm{d}\right)$ & 17 \\
Sludge load rate $(\mathrm{kg}$ COD $/ \mathrm{kg} \mathrm{VSS.d)}$ & 0.7 \\
HRT $(\mathrm{h})$ & 19.2 \\
Temperature $\left({ }^{\circ} \mathrm{C}\right)$ & 35 \\
MLSS $\left(\mathrm{Kg} / \mathrm{m}^{3}\right)$ & $30-50$ \\
Membrane area $\left(\mathrm{m}^{2}\right)$ & 0.44 \\
Flux $\left(\mathrm{L} / \mathrm{m}^{2}\right)$ & $0 \mathrm{ct}-40$ \\
Inlet Pressure $(\mathrm{kPa})$ & 340 \\
Cross-flow velocity $(\mathrm{m} / \mathrm{s})$ & 1.5 \\
Tube diameter $(\mathrm{mm})$ & 9
\end{tabular}

\section{Aerobic process}

Aerobic treatments proceed in an oxygen media using aerobic microorganisms. The process yields more microorganisms and byproducts of carbon dioxide, ammonia, and water. ${ }^{1}$ The processes involved include activated sludge, attached growth, and trickling filter. During the activated sludge process, wastewater passes through an aerated tank with sludge activated by a pool of bacteria, fungi, and protozoans. In the attached growth process, microorganisms are attached to a solid surface which creates an environment that promotes the growth of more microorganisms. In trickling filters, wastewater is sprayed over the bed of rough solids such as gravels, rocks, or plastics and can trickle down through a media of microorganisms.

\section{Anaerobic processes}

Anaerobic wastewater treatment proceeds without air during which organic matter turns into biogas with a composition of 55$75 \mathrm{vol} \%$ methane and $25-40$ vol\% carbon dioxide ${ }^{39}$ with negligible traces of hydrogen sulfide. Anaerobic treatment is applied in UASB and Fluidized Bed Reactors. In UASB digester, wastewater passes in the upward direction through a bed of sludge to allow contact of microorganisms with wastewater substrates ${ }^{40}$ Organic matter in the mixture is digested by microbes to release biogas which rises with some of the granular microbial blankets. At the top of the UASB reactor, separates biomass from biogas and wastewater. ${ }^{41}$

\section{Electrochemical methods}

Vijayaraghavan et al., ${ }^{42}$ demonstrated an electrical method for treating $\mathrm{BW}$ from hypochlorous acid which oxidizes organic compounds. An influent COD value of $2,470 \mathrm{mg} \mathrm{L}^{-1}$ reduced to $64 \mathrm{mg} \mathrm{L}^{-1}$ which indicates a $97 \%$ reduction. During this process, hypochlorous acid is produced using a graphite anode and a stainless steel cathode yielding chlorine at the anode and hydrogen gas at the cathode. Chlorine disproportionate in water to produce Hypochlorous acid according to Equation 2.

The further disproportion of to be catalyzed by alkaline conditions at the high temperature indicated in Equation 3.

BW has been treated to generate electricity microbial fuel cells. Wang et al., ${ }^{2}$ realized that wastewater influent of COD value $2,250 \pm 418 \mathrm{mg} \mathrm{L}^{-1}$, has a removal efficiency of $85 \%$ and $87 \%$ at $20^{\circ} \mathrm{C}$ and $30^{\circ} \mathrm{C}$ respectively using a MFC while the performance of a chronological anode-cathode microbial fuel cell resulted in a COD removal efficiency of more than $90 \% .^{12}$

\section{Uganda's Breweries sector and the future of BW treatment}

Uganda has two main breweries; the Nile breweries and Uganda breweries both located near good water sources. The reduction of water in the Nile basin initiated studies to quantify possible and feasible ways to utilize BW that result after brewing. Nile breweries Uganda Ltd has reduced its water consumption from $8 \mathrm{hL}$ of water per $\mathrm{hL}$ of beer produced in 2006 to a current consumption rate of less than $3.6 \mathrm{hL}$ of water per $\mathrm{hL}$ of beer produced. This wastewater has been treated to standards qualifying for floor washing in nonproduction areas as well as disposal back to the water stream. The treatment plant is also used to convert the organic waste into biogas as fuel to power some brewery machines (Brewers' Guardian, 2011). However, there is a need to explore alternative options to reuse BW. Production of electricity from the wastewater could be a good 
alternative to produce power to operate lighter equipment in the plant According to Wang et al., (2008) generating electricity from BW is a feasible economic activity. A power density of $12 \mathrm{~W} / \mathrm{m}^{3}$ and $11 \mathrm{~W} /$ $\mathrm{m}^{3}$ of electricity at $30^{\circ} \mathrm{C}$ and $20^{\circ} \mathrm{C}$ respectively from wastewater with a COD concentration ranging between 400 to $1400 \mathrm{mg} / \mathrm{L}$ was realized. The current production capacity of Nile Breweries stands at $2.45 \times 10^{5} \mathrm{~m}^{3}$ of beer annually which translates to about $2.45 \times 10^{6} \mathrm{~m}^{3}$ of waste water annually. Utilizing this waste water at a utilization rate of $70 \%$ indicates a power production of up to $20.58 \mathrm{MW}$ and 18.865 MW at $30^{\circ} \mathrm{C}$ and $20^{\circ} \mathrm{C}$ annually using a single chamber Microbial
Fuel Cells. This electricity is sufficient to operate small equipment in the plant thus reducing production costs. Treating wastewater for irrigation could be a potential for utilizing brewery wastewater. However, there could be higher costs involved in transportation that may hinder irrigation using this water. Thus, there is a need to explore the potential for utilization of the wastewater in energy production. The investment has a cost to benefit ratio of 0.224 as indicated in Table 7. This implies that more profits compared to losses are obtained from investing in electricity generation from industrial wastewater and has a payback period of about 2 years.

Table 7 Investing in energy generation

\begin{tabular}{|c|c|c|c|c|}
\hline No. & Item & Quantity & Unit cost & Total cost \\
\hline I & The volume of beer produced (Cubic meter) & 245000 & & \\
\hline 2 & Cost of producing a cubic meter of beer & $\$ 20$ & & $\$ 4,900,000$ \\
\hline 3 & Wastewater/cubic meter of beer & 10 to 20 & & \\
\hline 4 & Total wastewater produced (Cubic meter) & 2450000 & & \\
\hline 5 & Wastewater in system/day (Cubic meter) & 6712 & & \\
\hline 6 & Cost of water per Cubic meter & $\$ 1$ & & \\
\hline 7 & Cost of water annually & & & $\$ 2,450,000$ \\
\hline 8 & Microbial fuel cell (45L) & II 025 units & $\$ 895.65$ & $9,874,541.25$ \\
\hline 9 & Shipping of the cells & $10 \%$ of cells cost & & $987,454.13$ \\
\hline 10 & Taxes on importation & $30 \%$ of cells cost & & $2,962,362.38$ \\
\hline 11 & Total energy produced & $20.58 \mathrm{MW}$ & & \\
\hline 12 & Total KWh generated annually & $180,280,800.00$ & $\$ 0.64$ & || $5,379,7 \mid 2.00$ \\
\hline \multirow[t]{4}{*}{13} & VAT on energy sales & $18 \%$ & & $20,768,348.16$ \\
\hline & Benefits on energy sales & & & $94,6 \mathrm{II}, 363.84$ \\
\hline & Total costs & & & $\$ 21,174,358$ \\
\hline & Cost/Benefit Ratio & & & 0.224 \\
\hline
\end{tabular}

Production is based on a 365 days of Operation annually. The total volume of water supplied accounts for both wastewater and useful water. The fuel cells produce the energy of $18 \mathrm{~W}$ for every cubic meter of wastewater used. ${ }^{42-44}$

\section{Conclusion}

While information regarding the current use of BW by Uganda's main breweries. A lot can be picked from the highlighted current uses of wastewater from Breweries of the developing Countries and highlighted literature from authors in the rest of the world. This review indicates that $\mathrm{BW}$ has demonstrated potential in adaptation as irrigation water, electricity generation and biogas production. The wastewater can also be treated to standards sufficient for drinking, and washing thus reducing on costs of production for factories far from water sources. The sludge from treatment can be used in organic fertilizers. Usage of the wastewater in electricity generation has been explored which indicates potential for use of the wastewater.

\section{Acknowledgments}

None.

\section{Funding}

None.

\section{Conflicts of interest}

The authors declare there are no conflicts of interest.

\section{References}

1. Simate GS, Cluett J, Iyuke SE, et al. The treatment of brewery wastewater for reuse: State of the art. Desalination. 2011.

2. Wang H, Ren ZJ. ScienceDirect Bioelectrochemical metal recovery from wastewater: A review. Water Research. 2014;66:219-232.

3. Xiangwen S, Dangcong $\mathrm{P}$, Zhaohua $\mathrm{T}$, et al. Treatment of brewery wastewater using anaerobic sequencing batch reactor (ASBR). Bioresource Technology. 2008;99:3182-3186.

4. Papadopoulos KP, Economou CN, Tekerlekopoulou AG, et al. Twostep treatment of brewery wastewater using electrocoagulation and cyanobacteria-based cultivation. Journal of Environmental Management. 2020;265:110543.

5. Rocha T, Paulo P, Flavia E. Solid wastes in brewing process : A review. Journal of Brewing and Distilling. 2014;5(1):1-9.

6. Espinoza-Quiñones FR, Dall'Oglio IC, de Pauli AR, et al. Insights into brewery wastewater treatment by the electro-Fenton hybrid process: How to get a significant decrease in organic matter and toxicity. Chemosphere. 2020. 
7. Eyvaz M. Treatment of brewery wastewater with electrocoagulation: Improving the process performance by using alternating pulse current. International Journal of Electrochemical Science. 2016;11(6):49885008

8. Olajire AA. The brewing industry and environmental challenges. Journal of Cleaner Production. 2012:1-21.

9. Wang X, Feng YJ, Lee H. Electricity production from beer brewery wastewater using single chamber microbial fuel cell. Water Science and Technology. 2008;57(7):1117-1121.

10. Zhu F, Wang W, Zhang X, et al. Electricity generation in a membraneless microbial fuel cell with down-flow feeding onto the cathode. Bioresource Technology. 2011.

11. Zupančič GD, Škrjanec I, Marinšek Logar R. Anaerobic co-digestion of excess brewery yeast in a granular biomass reactor to enhance the production of biomethane. Bioresource Technology. 2012.

12. Wen $\mathrm{Q}, \mathrm{Wu} \mathrm{Y}, \mathrm{Cao} \mathrm{D}$, et al. Electricity generation and modeling of microbial fuel cell from continuous beer brewery wastewater. Bioresource Technology. 2009.

13. Larminie J, Dicks A. Fuel cell systems explained. In Fuel. 2003.

14. Pecharaply A, Parkpian P, Annachhatre AP, et al. Influence of anaerobic co-digestion of sewage and brewery sludges on biogas production and sludge quality. Journal of Environmental Science and Health Part A Toxic/Hazardous Substances and Environmental Engineering. 2007;42(7):911-923.

15. Manjunatha BN, Bhaskar S. Response of maize to brewer a terirrigation brewery and its effect on sub sequent paddy yield and soil subsequent quality. An International Quaterly Journal of Life Sciences. 2017;12(1):237-241.

16. Kanagachandran K, Jayaratne R. Utilization potential of brewery waste water sludge as an organic fertilizer. Journal of the Institute of Brewing. 2006;112(2):92-96.

17. Kadirvelu K, Thamaraiselvi K, Namasivayam C. Removal of heavy metals from industrial wastewaters by adsorption onto activated carbon prepared from an agricultural solid waste. Bioresource Technology. 2001 .

18. Patil SA, Surakasi VP, Koul S, et al. Electricity generation using chocolate industry wastewater and its treatment in activated sludge based microbial fuel cell and analysis of developed microbial community in the anode chamber. Bioresource Technology. 2009;100(21):5132-5139.

19. Alvarado-Lassman A, Rustrian E, García-Alvarado MA, et al. Brewery wastewater treatment using anaerobic inverse fluidized bed reactors. Bioresource technology. 2007;99(8):3009-3015.

20. Enitan AM, Adeyemo J, Kumari S, et al. Characterization of brewery wastewater composition. 2015;9(9):1073-1076.

21. Bamforth CW. Current perspectives on the role of enzymes in brewing. Journal of Cereal Science. 2009;50(3):353-357.

22. Jaiyeola AT, Bwapwa JK. Treatment technology for brewery wastewater in a water-scarce country: A review. South African Journal of Science. 2016 .

23. Fillaudeau L, Blanpain-Avet P, Daufin G. Water, wastewater and waste management in brewing industries. Journal of Cleaner Production. 2006 .

24. Arantes MK, Alves HJ, Sequinel R, et al. Treatment of brewery wastewater and its use for biological production of methane and hydrogen. International Journal of Hydrogen Energy. 2017;42(42):26243-26256.
25. UBOS. Uganda Bureau of Statistics; 2018 Statistical Abstract. Uganda Bureau of Statistics Statistics. 2018;1:204.

26. Van der Merwe A, Friend JFC. Water management at a malted barley brewery. Water SA. 2002;28(3):313-318.

27. Meda V. Size characterisation of industrial effluents for optimal selection of treatment technology (Issue December). 2004.

28. Hannöver W, Thyrian JR, Hapke U, et al. The Readiness to Change Questionnaire (RCQ) in subjects with hazardous alcohol consumption, alcohol abuse and -dependence in a general population survey. Alcohol and Alcoholism. 2002;37(4):362-369.

29. Agarwal A, Singhmar A, Kulshrestha M, et al. Municipal solid waste recycling and associated markets in Delhi, India. Resources, Conservation and Recycling, 2004;44(1):73-90.

30. Tarn K. Removal of multiple substrates in a mixed culture process for the treatment of brewery wastewater. In Department of Agricultural and Biosystems Engineering. McGill University Montreal. 2002.

31. Ince BK, Ince $\mathrm{O}$, Sallis PJ, et al. Inert cod production in a membrane anaerobic reactor treating brewery. 2000;34(16).

32. Goldammer T. The Brewer's Handbook. 2008. 496 p.

33. Huang H, Schwab K, Jacangelo JG. Pretreatment for Low Pressure Membranes in Water Treatment: A Review. Environmental Science \& Technology. 2009;43(9):3011-3019.

34. Gregory J. Particles in water. properties and processes (Issue c). 2006.

35. Braeken L, Van Der Bruggen B, Vandecasteele C. Regeneration of brewery waste water using nanofiltration. Water Research. 2004;38(13):3075-3082

36. Madaeni SS, Mansourpanah Y. Screening membranes for COD removal from dilute wastewater. Desalination. 2006;197(1-3):23-32.

37. Doubla A, Laminsi S, Nzali S, et al. Organic pollutants abatement and biodecontamination of brewery effluents by a non-thermal quenched plasma at atmospheric pressure.. Chemosphere. 2007;69(2):332-337.

38. Li XY, Chu HP. Membrane bioreactor for the drinking water treatment of polluted surface water supplies. Water Research. 2003;37(19):47814791.

39. Briggs DE, Boulton CA, Brookes PA, et al. Brewing Science and Practice. 2004.

40. Seneviratne M. Water conservation for commercial and industrial facilities. 2007.

41. Driessen W, Vereijken T. Recent developments in biological treatment of brewery effluent. The Institute and Guild of Brewing Convention, Livingstone, Zambia, March 2-7, 10. 2003.

42. Vijayaraghavan K, Ahmad D, Lesa R. Electrolytic treatment of beer brewery wastewater. Industrial and Engineering Chemistry Research. 2006;45(20):6854-6859.

43. Mathuriya AS, Sharma VN. Treatment of brewery wastewater and production of electricity through microbial fuel cell technology. International Journal of Biotechnology and Biochemistry ISSN, 2010;6(1):973-2691.

44. Papadopoulos KP, Economou CN, Dailianis S, et al. Brewery wastewater treatment using cyanobacterial-bacterial settleable aggregates. Algal Research. 2012;49:101957. 